\title{
Protective effect of aspirin on y radiation-induced sperm malformations in Swiss Albino male mice
}

\author{
Marowa Mansour AlMathkour, Entissar Suliman AlSuhaibani \\ College of Science, King Saud University, Riyadh, Saudi Arabia \\ Email address: \\ almatkour-marwa@hotmail.com (M. M. AlMathkour), ealsuhaibani@hotmail.com (E. S. AlSuhaibani)
}

To cite this article:

Marowa Mansour AlMathkour, Entissar Suliman AlSuhaibani. Protective Effect of Aspirin on $\gamma$ Radiation-Induced Sperm Malformations in Swiss Albino Male Mice. American Journal of Life Sciences. Vol. 2, No. 4, 2014, pp. 205-210. doi: 10.11648/j.ajls.20140204.13

\begin{abstract}
This study evaluated the effects of $\gamma$ radiation on spermatozoa based on the morphological characteristics of sperm in the caudal epididymis of SWR/J mice. In this study, various abnormal sperm shapes (amorphous heads, hook-less, mid-piece defect, pinheads, coiled tails, and tail-less) were observed after exposure to rirradiation (2 or 4 Gy)and after treatment with aspirin (ASA) and $\gamma$-irradiation $(0.5 \mathrm{mg} / \mathrm{kg}+2$ or $4 \mathrm{~Gy}, 5 \mathrm{mg} / \mathrm{kg}+2$ or $4 \mathrm{~Gy}$ and $50 \mathrm{mg} / \mathrm{kg}+2$ or $4 \mathrm{~Gy})$. The higher rate of abnormal sperm forms was observed in the $\gamma$-irradiated mice compared with the aspirin $+\gamma$-irradiationtreated mice. In addition, the numberof sperm with amorphous heads and coiled tails wassignificantly increasedafter irradiation. This study suggests that ASA can effectively reducethe effects of 2to4-Gy radiationin sperm. However, further studies are needed elucidate the mechanisms underlying the antioxidant effect of ASA.
\end{abstract}

Keywords: Aspirin, Sperm Malformation, Radioprotection

2006).However, the effect of low-dose radiation has not been comprehensively identified, and a number of studies are currently under way using invivo and invitro systems. An adaptive response, immunologicalenhancement, prolongation of life span, treatment or suppression of disease, and reduced chromosomal aberrations in experimental animals have been reported(Luckey, 1982; Caiet al., 1993).At the cellular level, the activation of a signaling pathway related to DNA damage and repair, apoptosis and cell proliferation has also been reported (Park etal., 1999; Gong et al., 2000).Moreover, the oxidative damage of DNA is induced by the generation of Reactive Oxygen Species (ROS) due to the application of exogenous chemicals, radiation or endogenous oxidative stress. Aspirin interacts with free radicals both directly and indirectly. Saini et al.,1998, reported that aspirin has the ability to scavenge or quench variousoxygen-free radicals or prevent their formation. Yonezawaet al.,1999, concluded that X-ray generates intracellular ROS and damages DNA directly and/or indirectly in Escherichia coli. However, the radiation effect in spermiogenesis after exposure to lowdose $(\leq 200 \mathrm{mGy})$ (UNSCEAR, 2000) and low-dose-rate ( $\leq$ $6 \mathrm{mGy} / \mathrm{h})$ irradiation has been found to be limited. The effects of radiation on human beings includemiscarriage, stillbirth, and malformation due to a genetic disorder in the paternal germ cell, as well as an increased incidence of

\section{Introduction}

Acetylsalicylic acid has analgesic, antipyretic and antiinflammatory effects and used primarily for the relief of minor pain, particularly pain of musculoskeletal origin (Booth, 1991). This and other non-steroidal antiinflammatory drugs are potent inhibitors of cyclooxygenase (prostaglandin synthetase), and the inhibition of this enzyme prevents the biosynthesis of prostaglandins (Campos et al., 1999). Hyaluronidase is anacrosomal enzyme that is required for the penetration of sperm through the cumulus oophorus matrix during fertilization (Lin et al., 1994). Hyaluronic acid is a component of the extracellular matrix that holds the follicular cells together and is degraded by sperm hyaluronidase (Joyce et al., 1986). A low activity of this enzyme causes a decrease in the fertilizing ability of sperm (Tanyıldızı and Bozkurt, 2002). Additionally, it has been reported that aspirin at a dose of $50 \mathrm{mg} / \mathrm{kg}$ body weight causes a decrease in the hyaluronidase and sorbitol dehydrogenase activities of rat semen (Didolkaret al., 1980). In addition, the harmful effects of high-dose radiation on a living organism, including human, have been well documented since the release of epidemiological data relating to the atomic bomb and the Chernobyl nuclear accident (Bennett et al., 


\subsection{Irradiation}

The mice were irradiated by a Cobalt-60 Source (Gamma cell-220, Nordion International Inc. Kanata. Canada) at the AlDreiah Radiation Unit of King Saud University. The mice were irradiated with doses of 2 Gy and 4Gy.The rate of radiation was $0.667 \mathrm{~Gy} / \mathrm{sec}$. Whole-body irradiation was administered to unanesthetized mice, which were placed in ventilated Perspex cages.

\subsection{Sperm Collection and Morphology Assessment}

Mice from each group were killed by cervical dislocation, and their cauda epididymides were removed. The sperm suspensions from each mouse were prepared by mincing the cauda in $2 \mathrm{ml}$ of physiological saline followed by, staining with $1 \%$ Eosin $\mathrm{Y}$. Thirty minutes after staining, smears were prepared, allowed to dry in air, and mounted under a cover slip with Per mount mounting medium. For each suspension, 1000 sperm were examined.

\subsection{Statistical Analysis}

Significant differences between the treated groups were tested using the Mann-Whitneytest. A value of $p<0.01$ was considered significant.

\section{Results}

This study assessed the protective effect of aspirin on $\gamma$ radiation-induced sperm malformation in Swiss Albino male mice. First, the distribution of sperm malformationswas compared between the negative control group of animals that were given distilled water and the group of animals that were injected with different aspirin concentrations. There was no significant difference found in the animals injected with $0.5 \mathrm{mg} / \mathrm{kg}$ aspirin. While there was significant difference found in animals that were injected with $5 \mathrm{mg} / \mathrm{kg}$, except two shapes of abnormal sperm, (pinhead and tail-less) which showed no significant differences. Also, the animals that were injected with 50 $\mathrm{mg} / \mathrm{kg}$ did not show any significant differences in one shape of abnormal sperm (pinhead), (Table 1). cancer (Dubrova, 2003; Nomura, 2006).In particular, the incidence of genetic disorders in the descendent generation is likely to result from genome instabilities in the parental generation (Tamminga, 2008).Due to the importance of the paternal germ cell in genetic disorders caused by radiation, the apoptosis rate, presence of gene mutations, repair capabilities, and chromosome aberrations of spermatogonia are used as endpoint markers in the evaluation (Cai and Wang, 1995; Liuet al., 2006).in addition, the pretreatment of Aspirin has provides protection against radiation induced structural chromosomal aberrations. The radio-protective role of Aspirin was found to be statistically significant(Al Mathkour and Al Suhaibani,2014). Therefore, the current study was designed to investigate the effect of aspirinon thereduction ofsperm damage induced by radiation.

\section{Materials and Methods}

\subsection{Experimental Animals}

Swiss albino male mice (Mus musculus; eight-week-old $\mathrm{SWR} / \mathrm{J}$ mice) with a body weight of $24 \pm 2 \mathrm{~g}$ were obtained from the animal house of King Saud University (Riyadh, Saudi Arabia).

\subsection{Treatments}

The animals were divided into three groups of five mice. The mice in group one were injected intraperitoneally (ip) with progressive aspirin concentrations $(0.5 \mathrm{mg} / \mathrm{kg}, 5 \mathrm{mg} / \mathrm{kg}$ and50 $\mathrm{mg} / \mathrm{kg}$ ). In contrast, the mice in group two were exposed to 2-Gy and 4-Gy $\gamma$ radiation and killed after $24 \mathrm{~h}$ from radiation. The mice in group three were injected with the same aspirin concentrations as group one $72 \mathrm{~h}$ before their whole body was exposed to 2-Gy and 4-Gy $\gamma$ radiation and killed after $24 \mathrm{~h}$ from radiation.

\subsection{Investigated Chemical}

The aspirin (Aspegic $($ ) ) used for the animalinjections, was purchased from Synthelabo France Le Plessis Robinson.

Table 1. Comparison of the distribution of sperm malformations between the negative control and the animals treated with different aspirin concentrations.

\begin{tabular}{|c|c|c|c|c|c|c|c|c|}
\hline \multirow{2}{*}{ Doses } & \multicolumn{8}{|c|}{ Frequency of sperm malformations } \\
\hline & Amorphous & Mid-piece defect & Hook-less & Pinhead & Coiled tails & Tail-less & Normal & Total \\
\hline Negative control & 323 & 0 & 77 & 74 & 214 & 15 & 4297 & 5000 \\
\hline $0.5 \mathrm{mg} / \mathrm{kg}$ & 323 & 0 & 77 & 74 & 214 & 15 & 4297 & 5000 \\
\hline$P$ value & Not sig. & Not sig. & Not sig. & Not sig. & Not sig. & Not sig. & & \\
\hline $5 \mathrm{mg} / \mathrm{kg}$ & 262 & 107 & 167 & 67 & 165 & 24 & 4208 & 5000 \\
\hline$P$ value & 0.01 & 0.01 & 0.01 & Not sig. & 0.01 & Not sig. & & \\
\hline $50 \mathrm{mg} / \mathrm{kg}$ & 296 & 119 & 166 & 70 & 169 & 30 & 4150 & 5000 \\
\hline Pvalue & 0.01 & 0.01 & 0.01 & Not sig. & 0.01 & 0.01 & & \\
\hline
\end{tabular}

(amorphous, mid-piece defect, hook-less, coiled tail, and tail-less) increased to $21.760 \%$ after exposure to $2-G y$ radiation. In contrast, the rate of spermmalformationswas
The analysis of the animals in group two, showed that the radiation significantly increased the rate of spermmalformation. The rates of sperm malformation 
found to be statistically significant at $\mathrm{P}<0.01$. In contrast, the rates of sperm malformationwere significantly decreased to $19.84 \%$ in the animals exposed to the same dose of $\gamma$ radiation and pretreated with $5 \mathrm{mg} / \mathrm{kg}$ aspirin. Additionally, there was a decrease in the rates of sperms malformationto $20.30 \%$ in the animals pretreated with 50 $\mathrm{mg} / \mathrm{kgaspirin}$ and exposed to 2-Gyradiation. The comparison of the spermmalformationsinduced by 2Gyradiation exposure only and those induced by 2-GY radiation with pre-treatment with different concentrations of aspirin are shown in Table 3.
$23.180 \%$ when the radiation dose was elevated to $4 \mathrm{~Gy}$ (Table 2, and Fig.1).

The analysis of the animals in group three showed that, pre-treatmentwith aspirin significantly reduced the percentage of sperm malformations (Table 1) compared with theanimals treated with radiation only. The animals exposed to 2-Gy radiation andpretreated with $0.5 \mathrm{mg} / \mathrm{kg}$ aspirin presented a percentage of sperm malformationsequal to $19.16 \%$, whereasthe animals exposed to the 2-Gy dose without aspirin exhibited a sperm malformation rate of, $21.760 \%$, and thisdifference was

Table 2. Comparison of sperm malformation after 2-Gy and 4-Gy radiation.

\begin{tabular}{|c|c|c|c|c|c|c|c|c|}
\hline \multirow{2}{*}{ Doses } & \multicolumn{8}{|c|}{ Frequency of sperm malformations } \\
\hline & Amorphous & Mid-piece defect & Hook-less & Pinhead & Coiled tails & Tail-less & Normal & Total \\
\hline Negative control & 323 & 0 & 77 & 74 & 214 & 15 & 4297 & 5000 \\
\hline 2 Gy & 421 & 162 & 206 & 97 & 155 & 64 & 3895 & 5000 \\
\hline$P$ value & 0.01 & 0.01 & 0.01 & 0.01 & 0.05 & 0.01 & & \\
\hline $4 G y$ & 414 & 170 & 212 & 117 & 170 & 76 & 3841 & 5000 \\
\hline$P$ value & 0.01 & 0.01 & 0.01 & 0.01 & 0.01 & 0.01 & & \\
\hline
\end{tabular}

Table 3. Comparison of sperm malformationsafter 2-Gy radiation exposure only and 2-Gy radiation exposure with different doses of aspirin.

\begin{tabular}{|c|c|c|c|c|c|c|c|c|}
\hline \multirow{2}{*}{ Doses } & \multicolumn{8}{|c|}{ Frequency of sperm malformations } \\
\hline & Amorphous & Mid-piece defect & Hook-less & Pin head & Coiled tails & Tail-less & Normal & Total \\
\hline 2 Gy & 421 & 162 & 206 & 97 & 155 & 64 & 3895 & 5000 \\
\hline $0.5 \mathrm{mg} / \mathrm{kg}+2 \mathrm{~Gy}$ & 343 & 159 & 168 & 66 & 172 & 41 & 4051 & 5000 \\
\hline$P$ value & 0.01 & 0.01 & 0.01 & 0.01 & 0.01 & 0.01 & & \\
\hline $5 \mathrm{mg} / \mathrm{kg}+2 \mathrm{~Gy}$ & 368 & 168 & 168 & 76 & 174 & 38 & 4008 & 5000 \\
\hline$P$ value & 0.01 & 0.01 & 0.01 & 0.01 & 0.01 & 0.01 & & \\
\hline $50 \mathrm{mg} / \mathrm{kg}+2 \mathrm{~Gy}$ & 366 & 185 & 173 & 79 & 169 & 43 & 3985 & 5000 \\
\hline Pvalue & 0.01 & 0.01 & 0.01 & 0.01 & 0.01 & 0.01 & & \\
\hline
\end{tabular}

decreased to $20.96 \%$ in the animals exposed to the same dose of $\gamma$ radiation andpretreated with $5 \mathrm{mg} / \mathrm{kgaspirin}$. Additionally, there was a significantdecrease in the rate of sperm malformationin the animals treated with 50 $\mathrm{mg} / \mathrm{kgaspirin}$ and exposed to the same dose of $\gamma$ radiation $(21.86 \%)$. The comparison of the sperm malformationsinduced by 4-Gy radiation exposure only and 4-Gy radiation with different doses of aspirinis shown in Table 4, and Fig.1.
A reasonable reduction in sperm malformationinduced by 4-Gy $\gamma$ radiation was noted inthe animals pretreated with different concentrations of aspirin. In the animals that were treated with $0.5 \mathrm{mg} / \mathrm{kg}$ aspirin and exposed to 4-Gy radiation, the rates of sperm malformationwere decreased to $20.08 \%$ compared to the rate of $23.180 \%$ observed in the animals exposed to 4-Gy radiation only, and this difference was found to be statistically significant at $P<0.01$. In contrast, the rates of sperm malformationwere significantly

Table 4. Comparison of sperm malformationafter 4-Gy radiation exposure only and 4-Gy radiation with different doses of aspirin.

\begin{tabular}{|c|c|c|c|c|c|c|c|c|}
\hline \multirow{2}{*}{ Doses } & \multicolumn{8}{|c|}{ Frequency of sperm malformations } \\
\hline & Amorphous & Mid-piece defect & Hook-less & Pin head & Coiled tails & Tail-less & Normal & Total \\
\hline 4 Gy & 414 & 170 & 212 & 117 & 170 & 76 & 3841 & 5000 \\
\hline $0.5 \mathrm{mg} / \mathrm{kg}+4 \mathrm{~Gy}$ & 366 & 172 & 175 & 79 & 171 & 41 & 3996 & 5000 \\
\hline$P$ value & 0.01 & 0.01 & 0.01 & 0.01 & 0.01 & 0.01 & & \\
\hline $5 \mathrm{mg} / \mathrm{kg}+4 \mathrm{~Gy}$ & 383 & 214 & 167 & 77 & 160 & 47 & 3949 & 5000 \\
\hline$P$ value & 0.01 & 0.05 & 0.01 & 0.01 & 0.01 & 0.01 & & \\
\hline $50 \mathrm{mg} / \mathrm{kg}+4 \mathrm{~Gy}$ & 392 & 215 & 179 & 143 & 175 & 53 & 3843 & 5000 \\
\hline Pvalue & 0.01 & 0.01 & 0.01 & 0.05 & 0.01 & 0.01 & & \\
\hline
\end{tabular}


$(\mathrm{P}<0.05)$ but relatively lower than the radio-protective provided with a low dose of aspirin $(0.5 \mathrm{mg} / \mathrm{kg})$.
The radio-protective effect obtained with an increase in theaspirin dose to $\mathrm{mg} / \mathrm{kg}$ and $50 \mathrm{mg} / \mathrm{kg}$ was significant
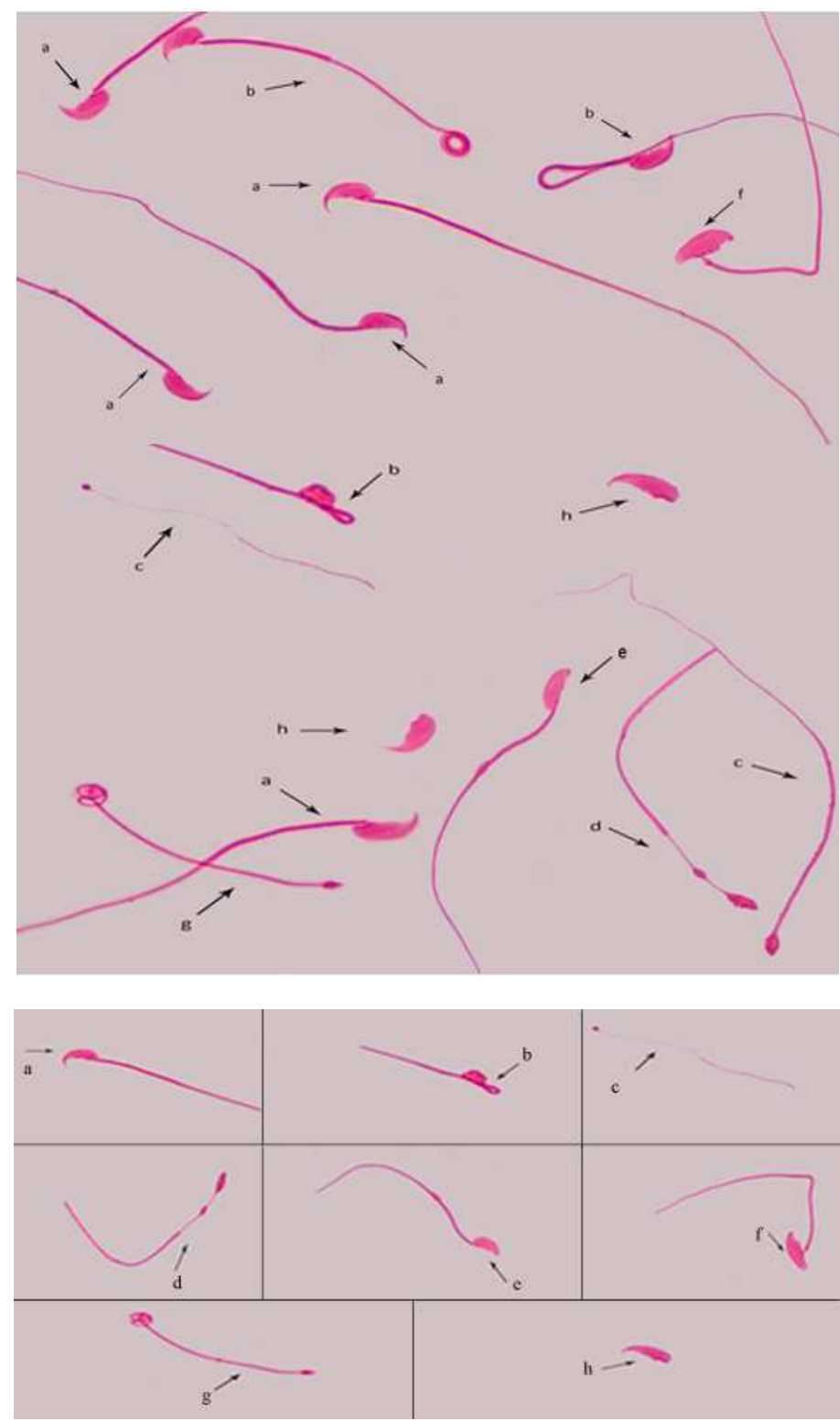

Fig 1. Images of some sperm malformation a: Normal sperm. b: Coiled-tail sperm. c: Pin head sperm. e: Hook-less sperm. f: Amorphous sperm g: Pinhead and Coiled-tail sperm .h: Tail-less sperm.

There are many hormones, biochemical processes and cellular events that occur during the formation of sperm. This process includes several stages, which give the cells the ability to become reproductive filial cellswhich in turn differentiate into sperm cells that are highly specialized. The process of the formation of these sperms includesvarious types of cells, such as Sertoli cells which produce a number of important proteins for the success of the process of production and spermatogenesis (Betka and Callard, 1999).

In the current study,the sperm malformation test was used to observe a number ofmalformations, in thehead, tail andin both the head and tail.In the group exposed to radiation, an increased number of sperm malformations was

\section{Discussion and Conclusions}

The process of sperm formation represents an essential step in the process of reproduction. This perpetual-motion processproduces millions of sperm a day in the right person to support the continuity oflife.Despite the importance of this processthe production mechanism of these sperm may be subject to disruption as a result of exposure to radiation or the administration of some anti-inflammatory medications. The complexity of the process of spermatogenesis makes it difficult to study the relationship between the observed effect and the reasonsfor the observed effect. 
research is required to clarify the mechanism of anticlastogenic and antioxidative of aspirin.

\section{Acknowledgment}

This project was supported by the Research Centerof the College of Science at King Saud University. The authors acknowledge the support provided by a research grant (No. aleph-tta-11-0576) by King Abdulaziz City of Science and Technology.

\section{References}

[1] Aubele, M., Jütting , U. Rodenacker , K., Gais , P., Burger , G. andHacker, U. (1990) .Quantitative evaluation of radiation-induced changes in sperm morphology and chromatin distribution. Cytometry. 11: 86-94.

[2] Betka,M. and Callard, G. (1999). Stage-dependent accumulation of cadmium and induction of metallothioneinlike binding activity in the testis of the dogfish shark Squaiusacanthias. Biology of Reproduction. 60:147-157.

[3] Bennett, B., Repacholi, M. and Carr, Z. (2006) Health Effect of the Chernobyl Accident and Special Health Care Programmes. Report of the UN Chernobyl Forum Expert Group "Health".

[4] Booth, N.H., 1991. Nonnarcotic analgesics. In: Booth, N.H., McDonald, L.E. (Eds.), Veterinary PharmacolgyandTherapeutics. Iowa State University Press, Ames, IA, pp. 329-346.

[5] Cai, L., Jiang, J., Wang, B., Yao, H. and Wang, X. (1993) Induction of an adaptive response to dominant lethality and to chromosome damage of mouse germ cells by low dose radiation. Mutation Research. 303: 157-161.

[6] Cai, L. and Wang, P. (1995) Induction of a cytogenetic adaptive response in germ cells of irradiated mice with very low-dose rate of chronic gamma-irradiation and its biological influence on radiation induced DNA or chromosomal damage and cell killing in their male offspring. Mutagenesis. 10:95-100.

[7] Campos, C., Gregorio, R., Garcia-Nieto, R., Gago, F., Ortiz, P., Alemany, S., 1999. Regulation of cyclooxygenase activity by metamizole. European Journal of Pharmacology. 378 (3): 339-347.

[8] Didolkar, A.K., Patel, P.B., Roychowdhury, D., 1980. Effect of aspirin on spermatogenesis in mature and immature rats. International Journal of Andrology. 3 (5), 585-593.

[9] Dubrova, Y. E. (2003) Radiation-induced transgenerational instability. Oncogene. 22(45): 7087-7093.

[10] Gomez, E., Onno, M., Drénou, B., Segretain, D., Alberti, ., S Lejeune, H., Fauchet, R., Jégou ,B. and Le Bouteiller, P. (1996). Expression of HLA class I genes in meiotic and post-meiotic human spermatogenic cells. Biology of Reproduction. 55:99-110.

[11] Gong, S. L., Liu, S. C., Liu, J. X., Zhang, Y. C. and Liu, S. Z. (2000) Adaptive response of thymocyte apoptosis and cell cycle progression induced by low dose X-ray irradiation in mice. Biomedical Environment Science. 13: 180-188. noted, and due to the effect of radiation on DNA, observation was detected in the semen of $25 \%$ of men with some type of infertility, who were also found to have high levels of oxygen ROS (Irving et al., 2000; Oliva, 2006). The relationship between DNA damage and sperm damage, lies in the presence of a defect during the process of spermatogenesis. The oxidative damage of DNA is induced by the generation of ROS due to the application of exogenous chemical, radiation or endogenous oxidative stress(Gomez et al., 1996), Themaintenance oflow levels of reactive oxygen species is necessary for sperm to function normally.

A number of studies suggest that the morphological damage observed in sperm reflects genetic damage in the germ cells. The evidence indicates that the sperm is formed fromgenetic material that is polygenetically controlled by the physical number of chromosomes and genes associated with sex. In addition, all mutagens that affect the cells of the mouse germ, including ionizing radiation, have been found to exhibit positive results when tested on sperm. A number of studies have demonstrated that exposingthe bodyto radiation clearly affects the endocrine and reproductive cells and leads to changes and abnormalities in sperm, and these studies conducted in the laboratory performed a quantitative analysis of the DNA content in sperm and recorded the changes evident in the form of the sperm and the distribution of chromatin, which are measures used to assess the effect of radiation on sperm (Aubeleet al., 1990).

Radiation particles may penetrate living tissues or cells as a result of the penetration of energy radioactive materials that are vitally important to the body of the organism, becausethe energy absorbed from ionizing radiation works to break chemical bonds and cause ionization of molecules of different components, including DNA, water and other vital components(Lett, 1992; Schulte and Bothe, 1991). In this study,less sperm malformation was observedin the group treated with aspirin prior to exposure to radiation compared with the groups that were expose to radiation only. These final results are compatible with those reported by Lee and Stupans in 2002, who demonstrated the ability of anti-inflammatory medications to protect tissues and cells from damage due to radiation. The findings of this study show the protective effect of aspirin on genotoxicity, because the results show a clear reduction in the incidence of sperm defects due to ionizing radiation after aspirin pretreatment.

Additionally, aspirin interacts with free radicals both directly and indirectly. Saini et al,.1998 reported that aspirin has the ability to scavenge or quench various oxygen-free radicals and/or prevent their formation.In our previous study, considered that NSAID's such as aspirin has the anticlastogenic ability and/or to protect DNA-damage by $\gamma$-ray. aspirin can be used as preventive agents against exposure to $\gamma$-ray (Al Mathkour and Al Suhaibani, 2014). Although the exact mechanism involved in the protective effect of aspirin is not clearly understood, more intensive 
[22] Park, S. H., Lee, Y., Jeong, K., Yoo, S. Y., Cho, C. K. and Lee, Y. S. (1999) Different induction of adaptive response to ionizing radiation in normal and neoplastic cells CellBiology. Toxicology. 15: 111-119.

[23] Saini, T., Bagchi, M., Bagchi, D., Jaeger, S.,Hosoyama, S. and Stohs, S.J. (1998). Protective ability of acetylsalicylic acid (aspirin) to scavenge radiation induced free radicals in J774A.1 macrophage cells. Research Community Molocular Pathology Pharmacology.101:259-268.

[24] Schulte, D. and Bothe, E. ; 1991 . The development of chemical damage of DNA in aqueous solution in : the early effects of radiation in DNA.Fielden, E.M.eds. Springer, Berlin.

[25] Tamminga, J., Koturbash, I., Baker, M., Kutanzi, K., Kathiria, P., Pogribny, I. P., Sutherland, R. J. and Kovalchuk, O. (2008) Paternal cranial irradiation induces distant bystander DNA damage in the germline and leads to epigenetic alterations in the offspring. Cell Cycle. 7(9): $1238-1245$.

[26] Tanyıldızı, S., Bozkurt, T., 2002. An investigation of the effects of ivermectin on blood serum, semen hyaluronidase activities and spermatological characteristics in sheep. Turkish Journal Veterinary Animal Science. 26: 353-357.

[27] UNSCEAR (2000) Volume I and II. United Nations sales publication E.00.IX.3 and E.00.IX.4 United Nations, New York.

[28] Yonezawa, Y., Miyaoshi, J., Takebe, H., Nishioka, H. (1999). Sensitivities and gene-expressions of Escherichia coli mutants deficient in DNA repair and reactive oxygen species scavenging capacity exposed to natural sunlight .Journal of Toxicology and Environmental Health .57 (4): 237 - 245.
[12] Irving, M., Weinstein, D. and Solomon.H.(1970) Acetylsalsalicacid : no chromosome damage in human leukocytes .Science 169 : 198-201.

[13] Liu, G., Gong, P., Zhao, H., Wang, Z., Gong, S. and Cai, L.(2006) Effect of low-level radiation onthe death of germ cells. Radiation research.165:379-389.

[14] Joyce, C.L., Mack, S.R., Anderson, R.A., 1986. Effects of hyaluronidase, beta-glucuronidase and beta- $N$ acetylglucosaminidase inhibitors on sperm penetration of the mouse oocyte. Biology Reproduction. 35: 336-346.

[15] Lee ,T. and Stupans ,I. (2002). Radioprotection: the nonsteroidal anti-inflammatory drugs (NSAIDs) and prostaglandins. Journal of Pharmacology. 54: 35-45.

[16] Lett, J. (1992). Damage to cellular DNA from development of Emphasis on DNA strand breaks and chromatin break. Radiation Environment Biophysiology .31: 257-277.

[17] Lin, Y.,Mahan, K., Lathrop,W.F.,Myles, D.G., Primakoff, P., 1994. A hyaluronidase activity of the sperm plasma membrane protein $\mathrm{PH}-20$ enables sperm to penetrate the cumulus cell layer surrounding the egg. J. Cell Biol. 125: $1157-1163$.

[18] Luckey, T. D. (1982) Physiological benefits from low levels of ionizing radiation. Health Physiology. 43:771-789.

[19] Marowa Al Mathkour and Entissar Al Suhaibani, 2014. Protective Effect of Aspirin on $\gamma$ Radiation Induced Chromosomal Aberrations in Swiss Albino Male Mice. Research Journal of Radiology, 1: 1-6.

[20] Nomura, T. (2006) Transgenerational effects of radiation and chemicals in mice and humans. J. Radiat.res.47:83-97.

[21] Oliva,R. (2006) .Protamines and male infertility. HumanReproductionUpdate .12:417-435. 